\title{
A Test of Two Methods for Waste Rock Drainage Quality Prediction: Aqua Regia Extraction and Single-addition Net-acid Generation Test Leachate Analysis
}

\author{
Teemu Karlsson $^{1,2} \cdot$ Lena Alakangas $^{2}\left[\right.$. Päivi Kauppila ${ }^{1} \cdot$ Marja Liisa Räisänen $^{3}$
}

Received: 18 March 2020 / Accepted: 5 May 2021 / Published online: 21 May 2021

(C) The Author(s) 2021

\begin{abstract}
The mobility of contaminants from mine waste can be assessed using different extraction methods. Aqua regia (AR) extraction is the most commonly used method in Finland. Another method is the analysis of leachate from net acid generation (NAG) tests, which is primarily designed for acid production potential assessment. We investigated the performance of single-addition NAG test leachate analysis and AR extraction in drainage quality prediction, using waste rock and drainage water samples from several Finnish waste rock sites. Our objective was to improve interpretation of the AR and singleaddition NAG test leachate analysis results in drainage quality prediction. The AR extraction effectively reflected elements that occurred in elevated concentrations in drainage water, though it over-predicted $\mathrm{Al}, \mathrm{As}, \mathrm{Cd}, \mathrm{Co}, \mathrm{Cu}$, and $\mathrm{Ni}$ in some circumneutral drainages, and $\mathrm{Cr}$ in general. The single-addition NAG test leachate analysis also performed well in assessing the mobility of contaminants including $\mathrm{Al}$ and $\mathrm{Cr}$ at acid mine drainage sites. As the contaminants tend to precipitate in neutral NAG test solution, the usability of the method in neutral mine drainage cases should be further investigated. Furthermore, the conclusions presented in this study are limited to waste rock samples collected from the surface of piles; future work will examine waste rock history, dump cores, drainage quality changes, etc. in more detail.
\end{abstract}

Keywords Mine waste characterisation $\cdot$ Drainage water $\cdot$ NAG test $\cdot$ ARD $\cdot$ NRD

\section{Introduction}

One of the main environmental issues associated with metal sulfide mining is generation of contaminated acid rock drainage (ARD) or neutral rock drainage (NRD) (e.g. Dold 2014; Heikkinen and Räisänen 2009; MEND 1991; Nieva et al. 2018; Price 2003; Singer and Stumm 1970). Mine waste facilities such as waste rock piles and tailings impoundments are the main sources of ARD and NRD (MEND 1991; Price 2003). Designing appropriate waste facilities and drainage

Teemu Karlsson

teemu.karlsson@gtk.fi

1 Circular Economy Solutions Unit, Geological Survey of Finland, P.O. Box 1237, 70211 Kuopio, Finland

2 Department of Civil, Environmental and Natural Resources Engineering, Division of Geosciences and Environmental Engineering, Luleå University of Technology, 97187 Luleå, Sweden

3 Industrial Environments and Recycling Unit, Geological Survey of Finland, P.O. Box 1237, 70211 Kuopio, Finland water management systems is important for mitigating the potential consequences of ARD or NRD but requires sufficient data about the long-term behaviour of the wastes. Thus, it is important to characterise mine wastes and assess their behaviour before actual mining activities begin.

The short- and long-term behaviour of mine wastes can be predicted by geochemical laboratory tests including static tests and longer-term kinetic tests, geochemical modelling, and using analogues from similar, older, mine waste sites (Kauppila and Räisänen 2015; Lapakko 2002; Muniruzzaman et al. 2018; Nordstrom and Nicholson 2017; Price et al. 1997; White III et al. 1999). The acid production potential of mine waste is usually determined based on different acid-base accounting (ABA) tests (Price 2009; Sobek et al. 1978), with the standardised method SFSEN 15875 (SFS-EN 2012) being widely used in Europe. Another commonly used method is the single-addition net acid generation (NAG) test (AMIRA 2002; Miller et al. 1997), which involves the reaction of a sample with hydrogen peroxide $\left(\mathrm{H}_{2} \mathrm{O}_{2}\right)$ to rapidly oxidise any sulfide minerals present. The ARD potential can also be calculated based on 
the mineralogy of the sample (Dold 2017; Karlsson et al. 2018b).

The mobility of contaminants from mine waste can be assessed using different extraction and selective leaching methods. Extraction with aqua regia (AR), a 3:1 mixture of hydrochloric acid and nitric acid (Doležal et al. 1968; Niskavaara 1995), is the most commonly used extraction method in mining environmental and mineral exploration studies in Finland. AR is intended to dissolve elements bound especially to sulfide phases, but in addition to sulfides, it also partly dissolves some silicates, and all carbonates and secondary precipitate minerals. As sulfides are the main primary sources of contaminants in mine wastes (e.g. Lapakko 2002), a sulfide-specific leaching method is useful in environmental studies to assess the potential mobility of elements (Niskavaara 1995). Based on previous studies, the AR-extractable concentrations of waste rocks indicate these contaminants are most likely to be of concern in mine waste drainage (Fosso-Kankeu et al. 2015; Karlsson and Kauppila 2016; Karlsson et al. 2018a; Price et al. 1997). In Finland, AR extraction is also the preferred method for evaluating whether mine waste is inert (Finnish Government 2013) and for assessing soil contamination (Finnish Government 2007; Reinikainen 2007). According to Finnish Government (2013), mine waste can be classified as inert if, among other criteria, the AR-extractable concentrations of As, $\mathrm{Cd}, \mathrm{Co}, \mathrm{Cr}, \mathrm{Cu}, \mathrm{Hg}, \mathrm{Mo}, \mathrm{Ni}, \mathrm{Pb}, \mathrm{V}$, and $\mathrm{Zn}$ do not exceed the threshold values or the background values (if the latter are naturally higher than the former), i.e. the socalled "PIMA values" defined in the Government Decree on Assessment of Soil Contamination and Remediation Needs (Finnish Government 2007).

Another method for contaminant mobility prediction is the analysis of leachate from the single-addition NAG test, which is primarily designed to determine the potential generation of acid in mine wastes (Barnes et al. 2015; Charles et al. 2015; Karlsson and Kauppila 2016; Karlsson et al. 2018a; Räisänen et al. 2010). The NAG test uses $\mathrm{H}_{2} \mathrm{O}_{2}$ to liberate acidity from Fe-sulfides. Räisänen et al. (2010) suggested that NAG leachate element concentrations could be useful for assessing contaminant mobility in long-term acid-generating reactions. Unlike AR, which cannot be used for drainage $\mathrm{pH}$ prediction, the NAG test combines the 'acid generating' and the 'fast reacting' acid neutralisation components and can predict the likely final $\mathrm{pH}$ of leachate from sulfidic mine waste. The extractability of trace elements during the NAG test can be considered representative of their potential mobilization in the long-term (Jennings et al. 2000; Lei and Watkins 2005; Weber et al. 2004). Analysis of NAG test leachate could also potentially be scaled to field conditions and used for preliminary prediction of mine waste seepage water quality (Barnes et al. 2015).
The objectives of the study were to: (1) improve the interpretation of AR extraction and single-addition NAG test leachate analysis results, (2) evaluate the functionality of NAG test leachate analysis as a proxy for natural sulfide oxidation, and (3) evaluate acid AR extraction for the preliminary assessment of mobility of contaminants. To achieve these objectives, we inspected the results of single-addition NAG test leachate analysis and AR extraction for waste rock samples collected from the surface of piles from various Finnish mine waste sites. We compared the AR and single-addition NAG test leachate results to actual measured drainage water compositions for selected surface composite samples. We also investigated and described waste rock characteristics and drainage water quality at several selected Finnish waste rock sites.

\section{Materials and Methods}

The rock materials analysed consisted of 49 waste rock samples (denoted 1-38, 101-111) collected from a total of 17 different locations: 14 active and closed metal mines, two industrial mineral mines and one dimension stone quarry in Finland (Table 1). Sampling was conducted during multiple field campaigns from 2013-2016.

Waste rock samples 1-38 consisted of a single rock type or mixed composite waste rock samples without corresponding drainage water data. Samples 101-111 were those used in Karlsson et al. (2018b) and consisted of $\approx 15-20 \mathrm{~kg}$ of heterogeneous rock material of particle size of $\approx 5-10 \mathrm{~cm}$ randomly collected from the surface of waste rock piles above drainage points, where water samples were collected for comparison. At Mine B, two sets of waste rock and water samples were taken from the same spot, the first in 2014 and the second in 2016. Mine $\mathrm{C}$ and Mine $\mathrm{G}$ have two different waste rock piles, an inactive older one and a new active one, which were sampled separately.

Waste rock drainage water samples were collected from small seepage streams flowing from the base of the waste rock piles at waste rock sampling sites 101-111. In two cases (Mine $\mathrm{C}$ new and Mine $\mathrm{A}$ ), there was no visible flow, and thus samples were taken from a pond at the base of the waste rock pile. The quality analysis of waste rock drainage water included field analysis of $\mathrm{pH}$ and electrical conductivity (EC) and laboratory analysis of dissolved elements. The field measurements were conducted using a portable multi-parameter YSI probe, which was calibrated to $\mathrm{pH} 4$ and 7 before every field trip. For dissolved element analysis, the drainage water samples were filtered in the field through $0.45 \mu \mathrm{m}$ filters into polyethylene bottles that had been rinsed twice with sample water and acidified with concentrated $\mathrm{HNO}_{3}$. 
Table 1 Sources of samples analysed and details of mine sites, including the major minerals, carbonates, sulphides and secondary minerals

\begin{tabular}{|c|c|c|c|c|c|c|c|c|}
\hline No & Mine site & Mine type & $\begin{array}{l}\text { Waste facility } \\
\text { active }\end{array}$ & $\begin{array}{l}\text { Rock/sample } \\
\text { type }\end{array}$ & $\begin{array}{l}\text { Main minerals } \\
(>5 \%)\end{array}$ & Carbonates & Sulfides & $\begin{array}{l}\text { Secondary } \\
\text { minerals }\end{array}$ \\
\hline 1 & Mine A & $\mathrm{Cu}-\mathrm{Zn}$ & 1973-1986 & $\begin{array}{l}\text { Chlorite biotite } \\
\text { schist }\end{array}$ & qtz, bt, chl & & po & \\
\hline 2 & Mine B & $\mathrm{Ni}$ & 1970-1993 & Serpentinite & srp, crs, ol & & & \\
\hline $3 *$ & Mine B & $\mathrm{Ni}$ & 1970-1993 & $\begin{array}{l}\text { Composite ser- } \\
\text { pentinite }\end{array}$ & $\mathrm{ol} / \mathrm{srp}, \mathrm{tlc}$ & $\mathrm{cc}$ & & gö/li \\
\hline $4^{*}$ & Mine B & $\mathrm{Ni}$ & 1970-1993 & $\begin{array}{l}\text { Composite mica } \\
\text { schist }\end{array}$ & $\mathrm{qtz}, \mathrm{pl}, \mathrm{bt}, \mathrm{ms}$ & & po, py, pe, ch & gö/li, ja \\
\hline $5^{*}$ & Mine B & $\mathrm{Ni}$ & 1970-1993 & $\begin{array}{l}\text { Composite mica } \\
\text { schist }\end{array}$ & $\mathrm{qtz}, \mathrm{ms}, \mathrm{bt}, \mathrm{pl}$ & & $\begin{array}{l}\text { po, pe, ch, py, } \\
\text { sph }\end{array}$ & gö/li \\
\hline $6^{*}$ & Mine B & $\mathrm{Ni}$ & 1970-1993 & $\begin{array}{l}\text { Composite ser- } \\
\text { pentinite }\end{array}$ & srp, ol & cc, sid & po, pe, ch & \\
\hline 7 & Mine $C$ old & Talc-Ni & 1982-2004 & Graphite schist & gr, po, qtz, bt, pl & & po, py & \\
\hline 8 & Mine $\mathrm{C}$ old & Talc-Ni & 1982-2004 & Soapstone & carb, tlc & carb & po, py & \\
\hline 9 & Mine D & $\mathrm{Cu}$ & 1966-1984 & Skarn rock & grt, ch, cpx & & ch, po & \\
\hline 10 & Mine D & $\mathrm{Cu}$ & 1966-1984 & Amphibolite & $\begin{array}{l}\text { hbl, pl, ep, cpx, } \\
\text { zs }\end{array}$ & & py, ch, po & \\
\hline 11 & Mine D & $\mathrm{Cu}$ & 1966-1984 & Skarn rock & grt, cpx, pl & & & \\
\hline 12 & Mine J & $\mathrm{Ni}-\mathrm{Cu}$ & 1988-1992 & $\begin{array}{l}\text { Graphite biotite } \\
\text { schist }\end{array}$ & $\begin{array}{l}\text { qrt, pl, bt, gr, } \\
\text { kfs, po }\end{array}$ & & po & \\
\hline 13 & Mine J & $\mathrm{Ni}-\mathrm{Cu}$ & 1988-1992 & Tonalite & $\mathrm{pl}, \mathrm{bt}, \mathrm{qtz}$ & carb & po, ch & \\
\hline 14 & Mine J & $\mathrm{Ni}-\mathrm{Cu}$ & 1988-1992 & $\begin{array}{l}\text { Amphibole } \\
\text { tonalite }\end{array}$ & $\mathrm{pl}, \mathrm{am}, \mathrm{qtz}, \mathrm{bt}$ & & po, ch, py & \\
\hline 15 & Mine K & $\mathrm{Zn}-\mathrm{Cu}$ & 1984-1985 & $\begin{array}{l}\text { Garnet biotite } \\
\text { schist }\end{array}$ & $\mathrm{qtz}, \mathrm{pl}, \mathrm{bt}, \mathrm{grt}$ & & py, po, ch & \\
\hline 16 & Mine L & $\mathrm{Cr}$ & 1968-2003 & Soapstone & tlc, carb, crm & carb & & \\
\hline 17 & Mine L & $\mathrm{Cr}$ & 1968-2003 & Soapstone & tlc, carb, crm & carb & & \\
\hline $18^{*}$ & Mine $\mathrm{R}$ & $\mathrm{Ni}-\mathrm{Cu}-\mathrm{PGE}$ & $2012-$ & $\begin{array}{l}\text { Composite } \\
\text { mixed waste } \\
\text { rock }\end{array}$ & di/am, srp & dol & & gö/li, gy \\
\hline $19^{*}$ & Mine $\mathrm{R}$ & $\mathrm{Ni}-\mathrm{Cu}-\mathrm{PGE}$ & $2012-$ & $\begin{array}{l}\text { Composite } \\
\text { mixed waste } \\
\text { rock }\end{array}$ & di/am, srp, hbl & dol & & gö/li, gy \\
\hline $20 *$ & Mine R & $\mathrm{Ni}-\mathrm{Cu}-\mathrm{PGE}$ & $2012-$ & $\begin{array}{l}\text { Composite } \\
\text { mixed waste } \\
\text { rock }\end{array}$ & di/am, srp, pl & $\mathrm{cc}$ & po, pe, ch & gö/li \\
\hline 21 & Mine M & $\mathrm{Zn}-\mathrm{Cu}-\mathrm{Pb}$ & 1758-1958 & $\begin{array}{l}\text { Cordierite } \\
\text { kyanite rock }\end{array}$ & $\begin{array}{l}\text { ky, qtz, crd, po, } \\
\text { ch }\end{array}$ & & po, ch, py & \\
\hline 22 & Mine M & $\mathrm{Zn}-\mathrm{Cu}-\mathrm{Pb}$ & 1758-1958 & $\begin{array}{l}\text { Chlorite musco- } \\
\text { vite talc schist }\end{array}$ & tlc, $\mathrm{ms}$ & & py, ch & \\
\hline $23^{*}$ & Mine N & $\mathrm{Cu}-\mathrm{Ni}-\mathrm{Zn}$ & $2011-$ & $\begin{array}{l}\text { Composite } \\
\text { mixed waste } \\
\text { rock }\end{array}$ & $\begin{array}{l}\text { pl, qtz, bt, phl, } \\
\text { py }\end{array}$ & $\mathrm{cc}, \mathrm{dol}$ & py, po, sph, pe & gy \\
\hline 24 & Mine $\mathrm{G}$ & $\mathrm{Au}$ & 2011- & Biotite schist & $\mathrm{qtz}, \mathrm{bt}, \mathrm{pl}, \mathrm{mgt}$ & & py & \\
\hline 25 & Mine $\mathrm{G}$ & $\mathrm{Au}$ & 2011- & Soapstone & tlc, carb & & py & \\
\hline 26 & Mine $\mathrm{O}$ & $\mathrm{Au}$ & 2014-2016 & Vulcanite & $\mathrm{qtz}, \mathrm{pl}, \mathrm{bt}, \mathrm{chl}$ & & po & \\
\hline 27 & Mine $\mathrm{O}$ & $\mathrm{Au}$ & 2014-2016 & Greywacke & $\mathrm{qtz}, \mathrm{pl}, \mathrm{bt}, \mathrm{ms}$ & & po & \\
\hline $28^{*}$ & Mine $\mathrm{O}$ & $\mathrm{Au}$ & 2014-2016 & $\begin{array}{l}\text { Composite } \\
\text { mixed waste } \\
\text { rock }\end{array}$ & $\mathrm{qtz}, \mathrm{bt}, \mathrm{pl}, \mathrm{chl}$ & & po, ch & \\
\hline $29 *$ & Mine I & $\mathrm{Ni}$ & 2007-2008 & $\begin{array}{l}\text { Composite mica } \\
\text { schist }\end{array}$ & bt, pl, qtz, chl & & po, py, pe, ch & gö/li \\
\hline $30^{*}$ & Mine I & $\mathrm{Ni}$ & 2007-2008 & $\begin{array}{l}\text { Composite mica } \\
\text { schist }\end{array}$ & $\begin{array}{l}\text { bt, pl, qtz, chl, } \\
\text { hbl, am }\end{array}$ & & po, py, ch & gö/li \\
\hline
\end{tabular}


Table 1 (continued)

\begin{tabular}{|c|c|c|c|c|c|c|c|c|}
\hline No & Mine site & Mine type & $\begin{array}{l}\text { Waste facility } \\
\text { active }\end{array}$ & $\begin{array}{l}\text { Rock/sample } \\
\text { type }\end{array}$ & $\begin{array}{l}\text { Main minerals } \\
(>5 \%)\end{array}$ & Carbonates & Sulfides & $\begin{array}{l}\text { Secondary } \\
\text { minerals }\end{array}$ \\
\hline 31 & Mine $\mathrm{P}$ & Diabase & $1994-$ & Metadiabase & $\mathrm{am}, \mathrm{pl}$ & & py, po & \\
\hline 32 & Mine $\mathrm{P}$ & Diabase & $1994-$ & Metadiabase & $\mathrm{am}, \mathrm{pl}$ & & py, po & \\
\hline 33 & Mine Q & $\mathrm{Cu}-\mathrm{Zn}-\mathrm{Ni}$ & 1972-1985 & Biotite schist & qtz, bt, po, py & & po, py, ch & \\
\hline 34 & Mine Q & $\mathrm{Cu}-\mathrm{Zn}-\mathrm{Ni}$ & 1972-1985 & Metapyroxenite & cpx, po & carb & po & \\
\hline 35 & Mine Q & $\mathrm{Cu}-\mathrm{Zn}-\mathrm{Ni}$ & 1972-1985 & $\begin{array}{l}\text { Amphibole } \\
\text { chlorite biotite } \\
\text { schist }\end{array}$ & bt, am, chl, po & & po & \\
\hline 36 & Mine Q & $\mathrm{Cu}-\mathrm{Zn}-\mathrm{Ni}$ & 1972-1985 & Kyanite quartzite & qtz, ky & & py, po & \\
\hline 37 & Mine Q & $\mathrm{Cu}-\mathrm{Zn}-\mathrm{Ni}$ & 1972-1985 & Serpentinite & srp, ol & carb & po & \\
\hline $38 *$ & Mine Q & $\mathrm{Cu}-\mathrm{Zn}-\mathrm{Ni}$ & 1972-1985 & $\begin{array}{l}\text { Composite } \\
\text { mixed waste } \\
\text { rock }\end{array}$ & $\mathrm{qtz}, \mathrm{pl}, \mathrm{bt}$ & $\mathrm{cc}$ & po, sph, py & gö/li, gy \\
\hline $101 *$ & Mine A & $\mathrm{Cu}-\mathrm{Zn}$ & 1973-1986 & $\begin{array}{l}\text { Composite waste } \\
\text { rock, drainage } \\
\text { sample }\end{array}$ & $\mathrm{qtz}, \mathrm{chl}, \mathrm{pl}, \mathrm{bt}$ & $\mathrm{cc}$ & po, ch, py & gö/li, gy \\
\hline $102 *$ & Mine B 2014 & $\mathrm{Ni}$ & 1970-1993 & $\begin{array}{l}\text { Composite waste } \\
\text { rock, drainage } \\
\text { sample }\end{array}$ & $\begin{array}{l}\text { qtz, bt, pl, srp, } \\
\text { po, ms }\end{array}$ & dol & po, py, ch, sph & gö/li \\
\hline $103 *$ & Mine B 2016 & $\mathrm{Ni}$ & 1970-1993 & $\begin{array}{l}\text { Composite waste } \\
\text { rock, drainage } \\
\text { sample }\end{array}$ & $\mathrm{pl}, \mathrm{bt}, \mathrm{qtz}, \mathrm{ms}$ & & po, py, ch, sph & gö/li \\
\hline $104 *$ & Mine $\mathrm{C}$ old & Talc-Ni & 1982-2004 & $\begin{array}{l}\text { Composite waste } \\
\text { rock, drainage } \\
\text { sample }\end{array}$ & $\begin{array}{l}\text { qtz, chl, pl, mgs, } \\
\text { tlc }\end{array}$ & mgs, dol, cc & po, py, pe & gö/li, gy \\
\hline $105^{*}$ & Mine $\mathrm{C}$ new & Talc-Ni & $2004-$ & $\begin{array}{l}\text { Composite waste } \\
\text { rock, drainage } \\
\text { sample }\end{array}$ & $\begin{array}{l}\text { qtz, bt, mgs, pl, } \\
\text { am, tlc }\end{array}$ & mgs, dol, cc & po, py, pe & \\
\hline $106^{*}$ & Mine D & $\mathrm{Cu}$ & 1966-1984 & $\begin{array}{l}\text { Composite waste } \\
\text { rock, drainage } \\
\text { sample }\end{array}$ & $\mathrm{pl}, \mathrm{hbl}$, aug, qtz & $\mathrm{cc}$ & ch, po, py & \\
\hline $107 *$ & Mine E & $\mathrm{Au}$ & 2011-2013 & $\begin{array}{l}\text { Composite waste } \\
\text { rock, drainage } \\
\text { sample }\end{array}$ & $\begin{array}{l}\mathrm{pl}, \mathrm{qtz}, \mathrm{kfs}, \mathrm{bt}, \\
\mathrm{am}, \mathrm{hbl}\end{array}$ & & po & \\
\hline $108^{*}$ & Mine F & $\mathrm{Au}$ & $2011-$ & $\begin{array}{l}\text { Composite waste } \\
\text { rock, drainage } \\
\text { sample }\end{array}$ & $\mathrm{pl}, \mathrm{kfs}, \mathrm{bt}, \mathrm{qtz}$ & dol, sid, cc & ch, po & gö/li \\
\hline $109^{*}$ & Mine G old & Apatite & $1975-2000 ?$ & $\begin{array}{l}\text { Composite waste } \\
\text { rock, drainage } \\
\text { sample }\end{array}$ & $\begin{array}{l}\text { bt, cc, hbl, phl, } \\
\text { dol }\end{array}$ & $\mathrm{cc}, \mathrm{dol}$ & po & \\
\hline $110^{*}$ & Mine G new & Apatite & 2000?- & $\begin{array}{l}\text { Composite waste } \\
\text { rock, drainage } \\
\text { sample }\end{array}$ & $\mathrm{pl}, \mathrm{kfs}, \mathrm{bt}$, aug & $\mathrm{cc}$ & py, po & \\
\hline $111^{*}$ & Mine $\mathrm{H}$ & $\mathrm{Ni}$ & 2007-2008 & $\begin{array}{l}\text { Composite waste } \\
\text { rock, drainage } \\
\text { sample }\end{array}$ & bt, pl, qtz, hbl & & po, pe, py & gö/li \\
\hline
\end{tabular}

Minerals are presented in descending order of concentration. The amounts of detected secondary minerals were low $(0.1-0.01 \%)$. Samples marked with an asterisk were analysed by FE-SEM on milled samples and other samples by light microscopy on thin sections of whole rock

alb, albite; am, amphibole; ap, apatite; aug, augite; bt, biotite; carb, undefined carbonate; cc, calcite; ch, chalcopyrite; chl, chlorite; cpx, clinopyroxene; crd, cordierite; crm, chromite; crs, chrysotile; di, diopside; dol, dolomite; ep, epidote; gö, göthite; gr, graphite; grt, garnet; gy, gypsum; hbl, hornblende; ilm, ilmenite; ja, jarosite; kfs, k-feldspar; ky, kyanite; li, limonite; mgs, magnesite; mgt, magnetite; ms, muscovite; ol, olivine; opx, orthopyroxene; pe, pentlandite; phl, phlogobite; pl, plagioclase; po, pyrrhotite; py, pyrite; qtz, quartz; rt, rutile; sid, siderite; sph, sphalerite; srp, serpentine; tlc, talc; tt, titanite; zr, zircon; zs, zoisite 
The drainage water and surface waste rock samples were analysed in alaboratory of Labtium Oy Eurofins Labtium Oy, which has been accredited by FINAS (Finnish Accreditation Service) using the ISO/IEC 17025 standard (ISO/IEC 2005). Drainage water dissolved element concentrations were analysed by ICP-OES and ICP-MS. The rock samples were first dried at $<40{ }^{\circ} \mathrm{C}$ and then crushed $(>70 \%<2 \mathrm{~mm})$. For the different laboratory analyses, the crushed samples were split using a riffle splitter and/or the cone and quartering method and milled in a steel container. The XRF method (Criss and Birks 1968) was used to obtain the total elemental concentrations. The XRF method is not suitable for some elements, e.g. $\mathrm{Cd}$ and Co. The total concentrations of $\mathrm{C}$ and $\mathrm{S}$ were determined using the ISO 10694 (ISO 1995a) and ISO 15178 (ISO 2000) standards respectively, using a pyrolytic method (Leco) and infrared (IR) detection. Noncarbonate $\mathrm{C}$ was determined after hydrochloric acid treatment by pyrolysis and IR detection. The amount of carbonate $\mathrm{C}$ was calculated based on the difference between total $\mathrm{C}$ and non-carbonate C (ISO 1995a). Main and trace element concentrations were determined with a hot AR extraction method and ICP-OES/MS techniques (Niskavaara 1995), using a modified version of the ISO-11466 standard (ISO 1995b) to dissolve the samples.

The single-addition NAG test was performed following instructions in the AMIRA handbook (AMIRA 2002). The test involves mixing $250 \mathrm{~mL}$ of $15 \%(\mathrm{~m} / \mathrm{V}) \mathrm{H}_{2} \mathrm{O}_{2}$ with $2.5 \mathrm{~g}$ of pulverised sample. The laboratory uses ultra-pure $\mathrm{H}_{2} \mathrm{O}_{2}$ when analysing NAG test leachate for trace element concentrations, as recommended by Ross and Verburg (2015). The mixture reacted for $12 \mathrm{~h}$, after which it was boiled until the visible reaction ceased. After cooling, EC, $\mathrm{pH}$ and concentrations of dissolved main and trace elements in the NAG leachate were determined by ICP-OES/MS, and the suspension was titrated with $\mathrm{NaOH}(0.1 \mathrm{~mol} / \mathrm{L})$ to $\mathrm{pH} 4.5$ and 7.0 (AMIRA 2002).

The quality of drainage water and waste rock analysis was assured by the accredited laboratory by analysing control samples and providing the quality control analysis results along with the sample results. In addition, laboratory duplicates for 10 waste rock and three drainage water samples were analysed. The quality of the drainage water samples was further checked by taking double and blank (laboratory distilled water) samples during the field campaigns after approximately every 10 samples.

\section{Results}

\section{Geochemistry of the Surface Waste Rock Samples}

Geochemical analysis results, including total S, total C, carbonate $\mathrm{C}$, total elements, NAG test leachate $\mathrm{pH}$, and element concentrations in AR and NAG test leachates, are presented in supplemental Table S-1. AR-extractable concentrations are also compared with the reference values defined by Finnish Government (2007) in Table S-1. For samples 101-111, the above-mentioned parameters are also presented in Table 2.

Total S concentration in the samples varied from $<0.05 \%$ in several samples to $10.4 \%$ of the skarn rock sample no. 9 from Mine D. The median of all samples was $0.6 \%$. Of 49 samples, 11 had a very low $\mathrm{S}$ concentration of $0.1 \%$ or less. Total $\mathrm{C}$ concentration in the samples varied from $<0.05 \%$ in several samples to $9.5 \%$ for the graphite schist sample no. 7 from Mine $\mathrm{C}$ old site (median $0.3 \%$ ). Carbonate $\mathrm{C}$ concentration in the samples varied from $<0.05 \%$ to $6.5 \%$ (median $0.1 \%$ ). The $\mathrm{pH}$ of NAG test leachate varied from 2.4 to 10.8 (median 4.1). Based on NAG pH $<4.5,26$ of the 49 samples were classified as potentially acid forming (AMIRA 2002).

Based on the AR-extractable element concentrations, only the garnet biotite schist sample from Mine K (sample no. 16) was classified as inert (Table S-1). All the other samples contained contaminant concentrations exceeding the PIMA threshold values for harmful elements set by Finnish Government (2007). In particular, the $\mathrm{Ni}, \mathrm{Cu}$, and $\mathrm{Cr}$ concentrations exceeded the upper guideline values for 31 out of 49 , 27 out of 49, and 11 out of 49 samples, respectively. Zn concentrations exceeded the upper PIMA guideline value for six samples, As concentrations for five samples, and $\mathrm{Co}$ concentrations for one sample.

On average, $A R$ extracted $\approx 40 \%$ of the total (XRF detectable) $\mathrm{Al}$ and $\mathrm{Cr}$. For Fe, $\mathrm{Mn}$, and $\mathrm{Zn}$, the average AR extractable amount was $\approx 60-70 \%$, for As and $\mathrm{Ni} \approx 80 \%$, and for $\mathrm{Cu}$ and $\mathrm{S}>90 \%$. For $\mathrm{Cd}$ and $\mathrm{Co}$, the AR results could not be compared with the total element concentrations, as no XRF results were available for $\mathrm{Cd}$ and $\mathrm{Co}$. In general, the element concentrations in NAG test leachate were substantially less than the AR-extractable concentrations. The only exception was $\mathrm{Cd}$, for which the NAG test leachable concentration was higher than the AR-extractable concentration in nine of the 49 samples (Table S-1). This might be due to the relatively low $\mathrm{Cd}$ concentrations, which were approaching the limit of quantification.

Ratios of element concentrations in single-addition NAG test leachate to AR-extractable concentrations (NAG/AR ratios) are presented in Fig. 1. Data points were removed if the extractable concentrations were below the detection limit (e.g. $\mathrm{Zn}$ for samples no. 16 and 17), or if the detection limit for NAG analysis exceeded the AR-extractable concentration (e.g. Fe for sample no. 8).

In general, for most of the elements analysed the NAG/ AR ratio was markedly lower than 1.0, indicating that the concentrations in NAG leachate were lower than those in AR solution. In addition, the NAG/AR ratio was higher when the NAG test leachate $\mathrm{pH}$ was low, and vice versa (Fig. 1). 


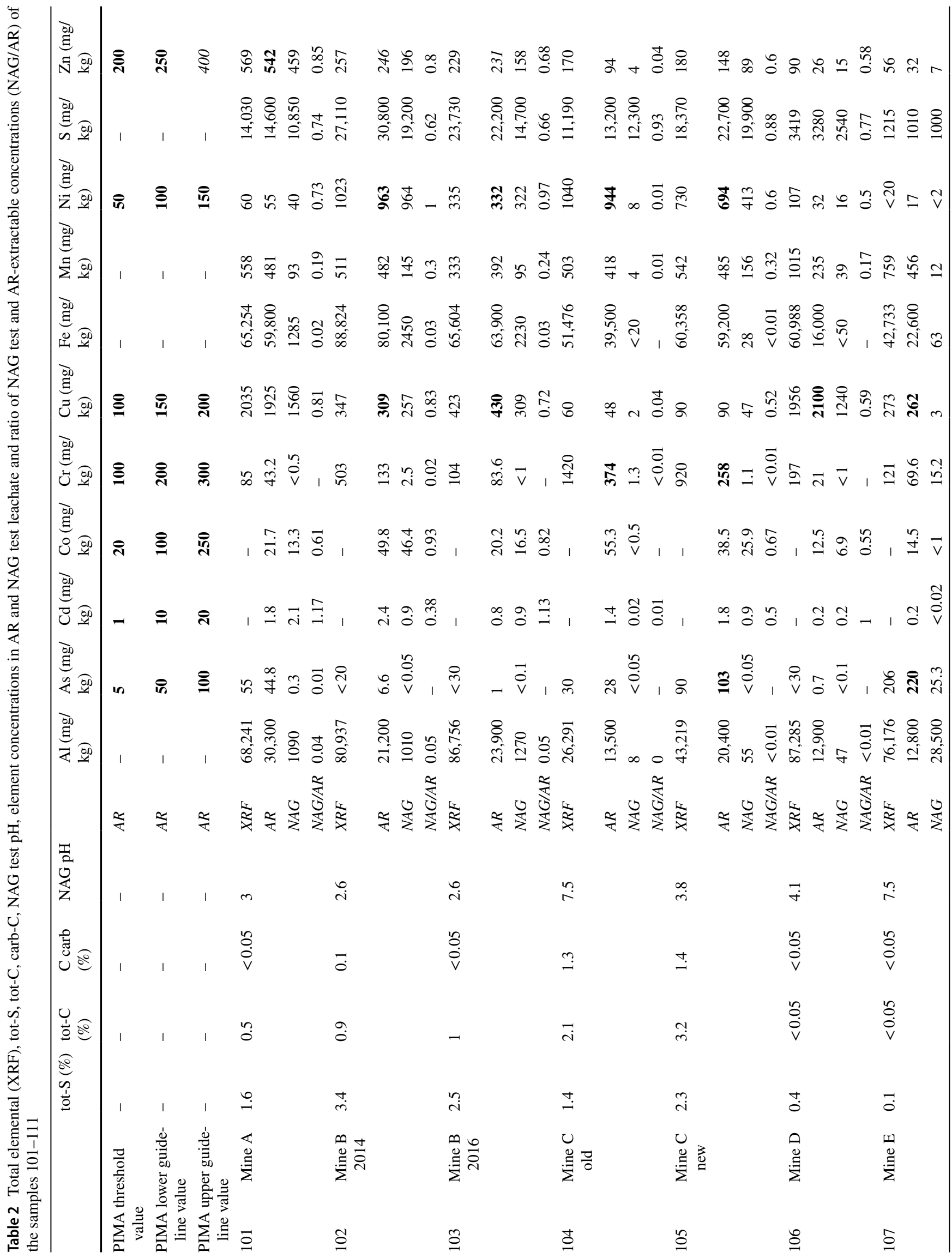


742

Mine Water and the Environment (2021) 40:736-751

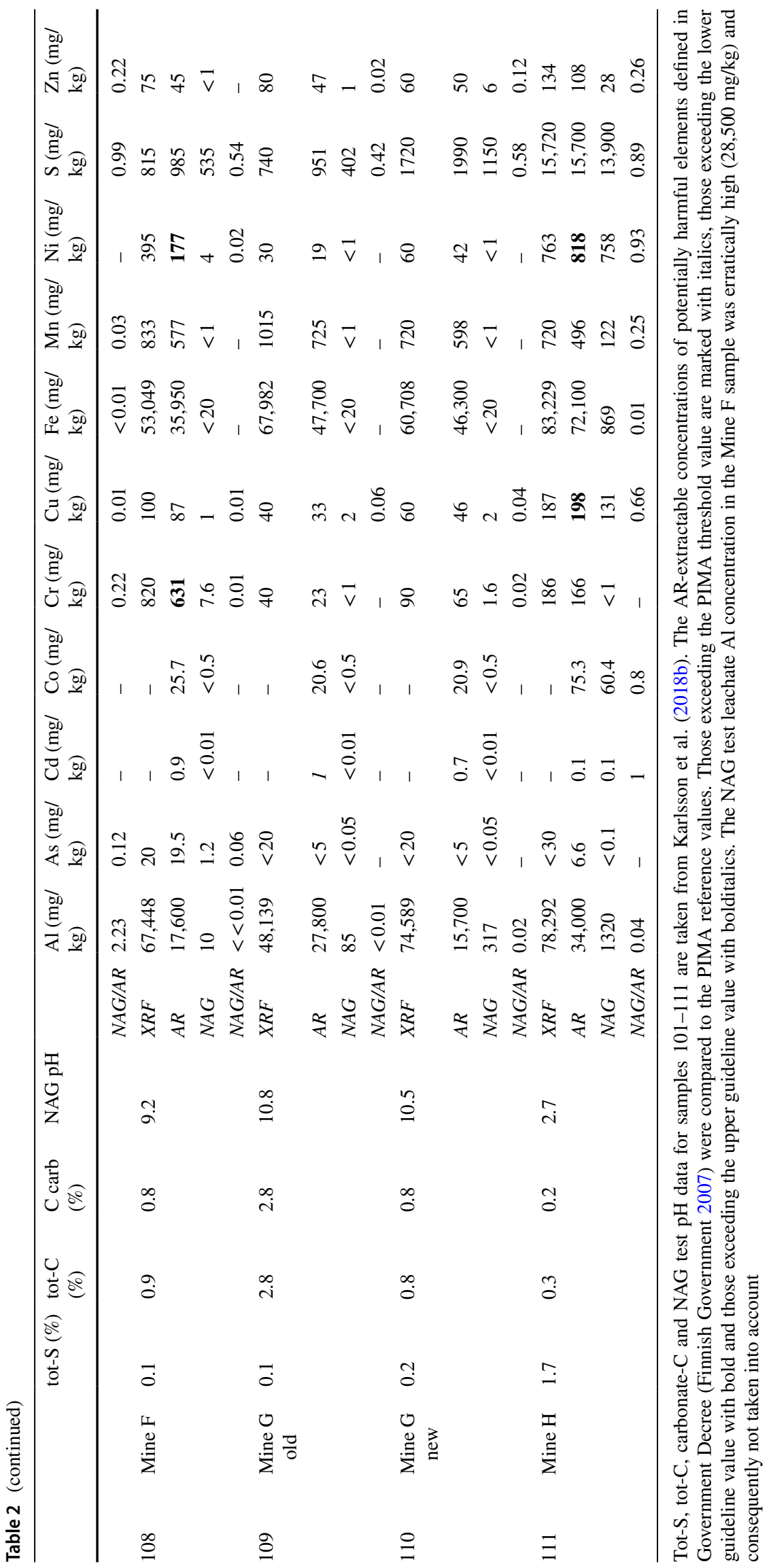

Springer 
Al

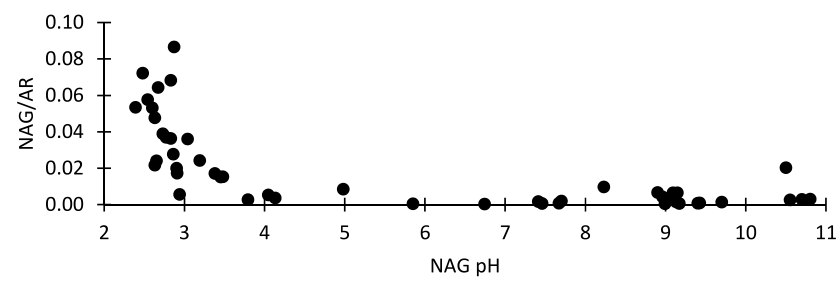

Cd

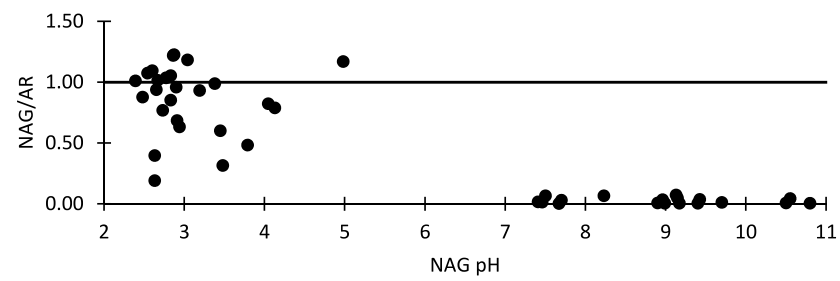

$\mathrm{Cr}$

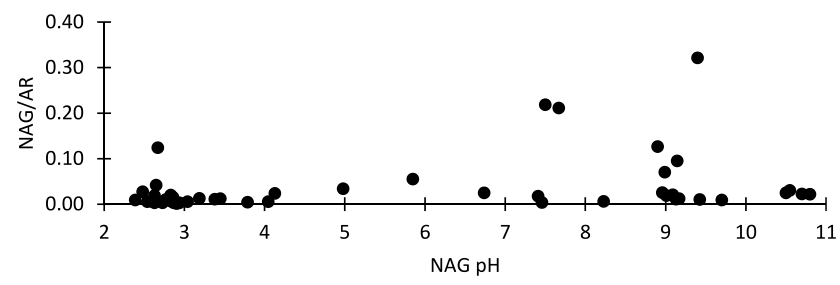

Fe

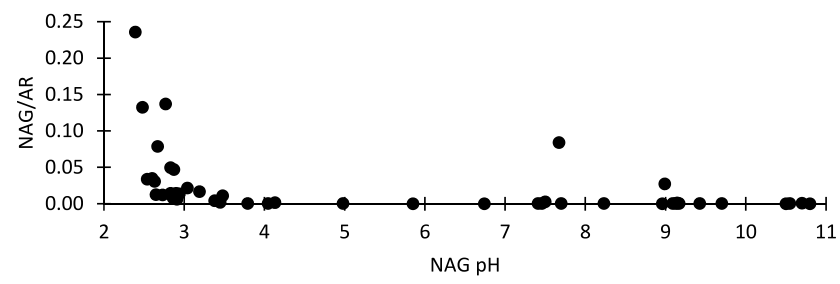

$\mathrm{Ni}$

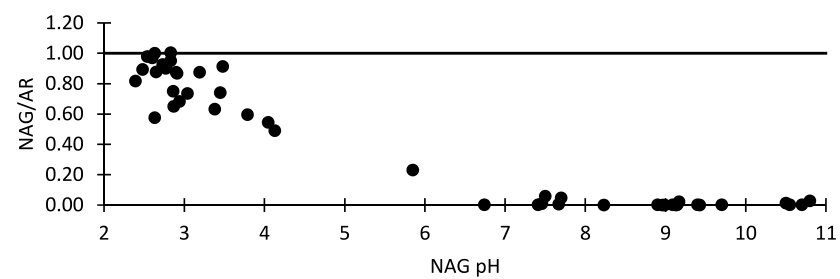

Zn

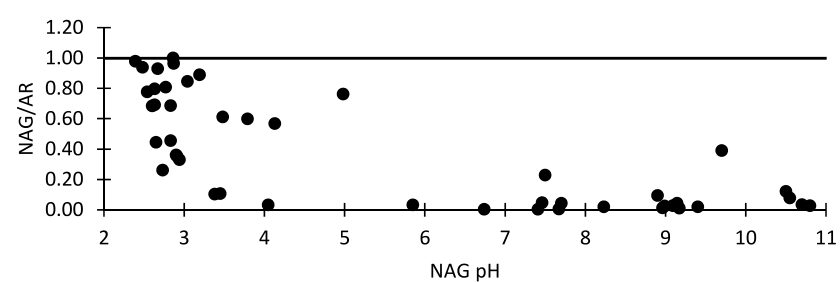

As

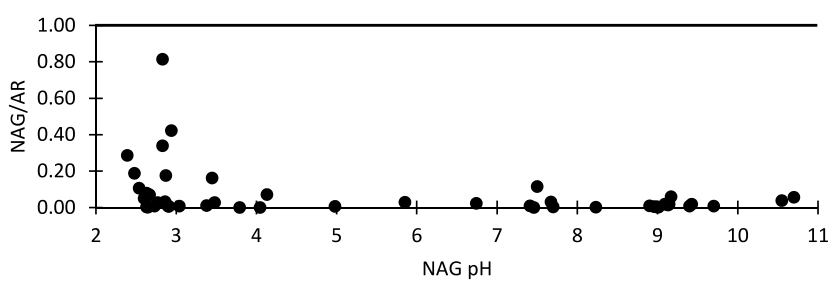

Co

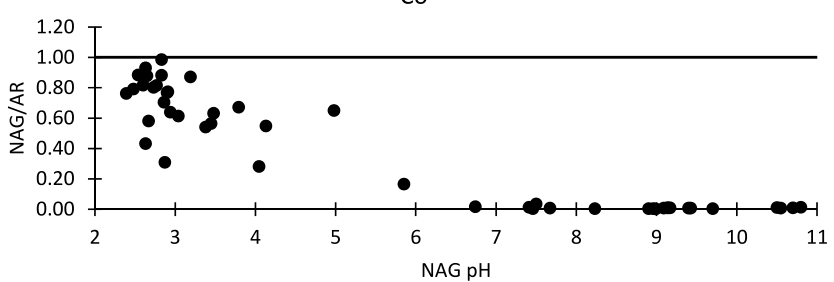

$\mathrm{Cu}$

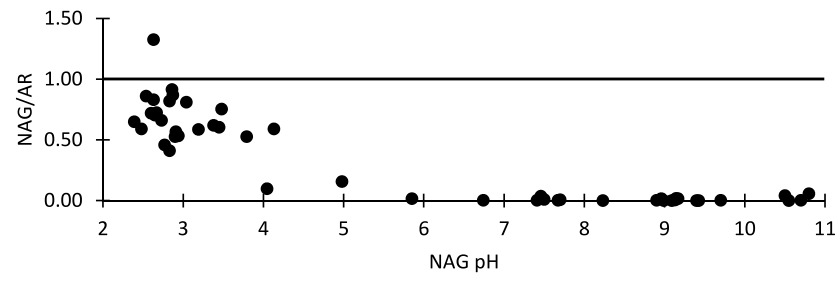

$\mathrm{Mn}$

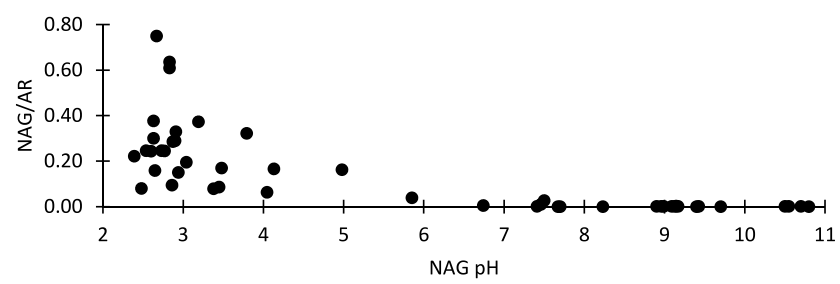

S

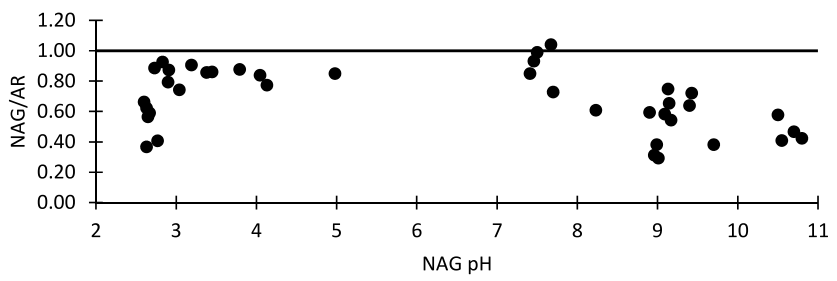

Fig. 1 Ratio of NAG test leachate concentration to AR-extractable concentration of Al, As, Cd, Co, Cr, Cu, Fe, Mn, Ni, S and Zn (Y-axis) as a function of NAG test leachate $\mathrm{pH}$ (X-axis). The NAG/AR ratio 1.0 is marked with a horizontal line 


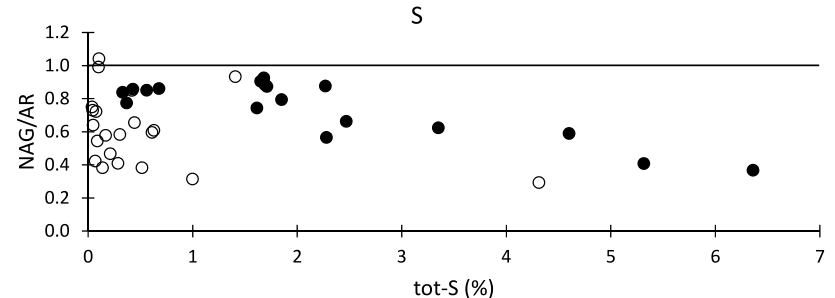

Fig. 2 Ratio of NAG test leachate concentration to AR-extractable concentration for sulphur (S) as a function of total $\mathrm{S}$ concentration. Samples with NAG $\mathrm{pH}>7$ presented as white dots. The NAG/AR ratio 1.0 is marked with a horizontal line

This was particularly true for $\mathrm{Al}, \mathrm{As}, \mathrm{Cd}, \mathrm{Cu}, \mathrm{Co}, \mathrm{Cu}, \mathrm{Ni}$, $\mathrm{Zn}, \mathrm{Fe}$, and $\mathrm{Mn}$. The NAG/AR ratios of $\mathrm{Cd}, \mathrm{Co}, \mathrm{Cu}, \mathrm{Mn}$, $\mathrm{Ni}$ and $\mathrm{Zn}$ were clearly lower at $\mathrm{pH}$ 5-6 than in more acidic conditions, but were still above or $\approx 0.2$. However, when the $\mathrm{NAG} \mathrm{pH}>6$, the ratios dropped close to 0.01 , except for $\mathrm{Zn}$, which showed some sporadic higher ratios at higher NAG $\mathrm{pH}$. In contrast to these metals, $\mathrm{Cr}$ showed higher NAG/ $\mathrm{AR}$ ratios at $\mathrm{pH}>7$ than at low $\mathrm{pH}$. In general, the leachability of $\mathrm{Cr}$ was lower in the NAG test than in AR extraction (ratio <0.3). Leachability of $\mathrm{Al}$ and $\mathrm{Fe}$ in the NAG test was generally low in comparison with their extractability in AR, with NAG/AR ratios below 0.1 and 0.25 , respectively (Fig. 1). For Al, As, and Fe, the NAG/AR ratio was mainly below 0.01 when the NAG $\mathrm{pH}$ was $>4$. For $\mathrm{S}, \mathrm{NAG} / \mathrm{AR}$ ratios above 0.8 were abundant when the $\mathrm{NAG} \mathrm{pH}$ was $<8$, but not when $\mathrm{NAG} \mathrm{pH}>8$. In general, the NAG test leachate $\mathrm{pH}$ did not clearly affect the NAG/AR ratios of S. Samples with $<0.2$ wt.\% of total $\mathrm{S}$ had NAG/AR ratios ranging from $\approx 0.4$ to 1 and a NAG $\mathrm{pH}>7$ (Fig. 2). For samples with a lower NAG $\mathrm{pH}$ and a total $\mathrm{S} \approx 2 \mathrm{wt} . \%$, the NAG/AR ratio for $\mathrm{S}$ was above 0.7 and decreased below 0.4 when the total $\mathrm{S}$ was $\approx 6$ wt.\% (Fig. 2).

\section{Drainage Water Quality}

The $\mathrm{pH}$ of the drainage samples ranged from 3.3 (Mine $\mathrm{H}$ ) to 7.7 (Mine $\mathrm{C}$ new) with a median value of 6.7 (Karlsson et al. 2018b). EC ranged from $597 \mu \mathrm{S} / \mathrm{cm}$ (Mine D) to $4577 \mu \mathrm{S} / \mathrm{cm}$ (Mine $\mathrm{C}$ old) with a median value of $1731 \mu \mathrm{S} / \mathrm{cm}$ (Table 3). The drainage water concentrations were compared with the Finnish stream water medians presented by Lahermo et al. (1996). The concentrations were $>100 \times$ Finnish stream water medians for $\mathrm{SO}_{4}$ at eight of the 10 target waste rock sites (seven of eight mines), for $\mathrm{Ni}$ and $\mathrm{Co}$ at six waste rock sites (five mines), for $\mathrm{Cu}$ at four waste rock sites (four mines), for $\mathrm{Al}, \mathrm{Mn}$, and $\mathrm{Zn}$ at two waste rock sites (two mines), and for $\mathrm{Pb}$ at one waste rock site (one mine). The $\mathrm{Cd}$ concentrations were relatively high at five waste rock sites (five mines): Mines A, B, C old, D, and $\mathrm{H}$, where the concentrations in drainage water exceeded

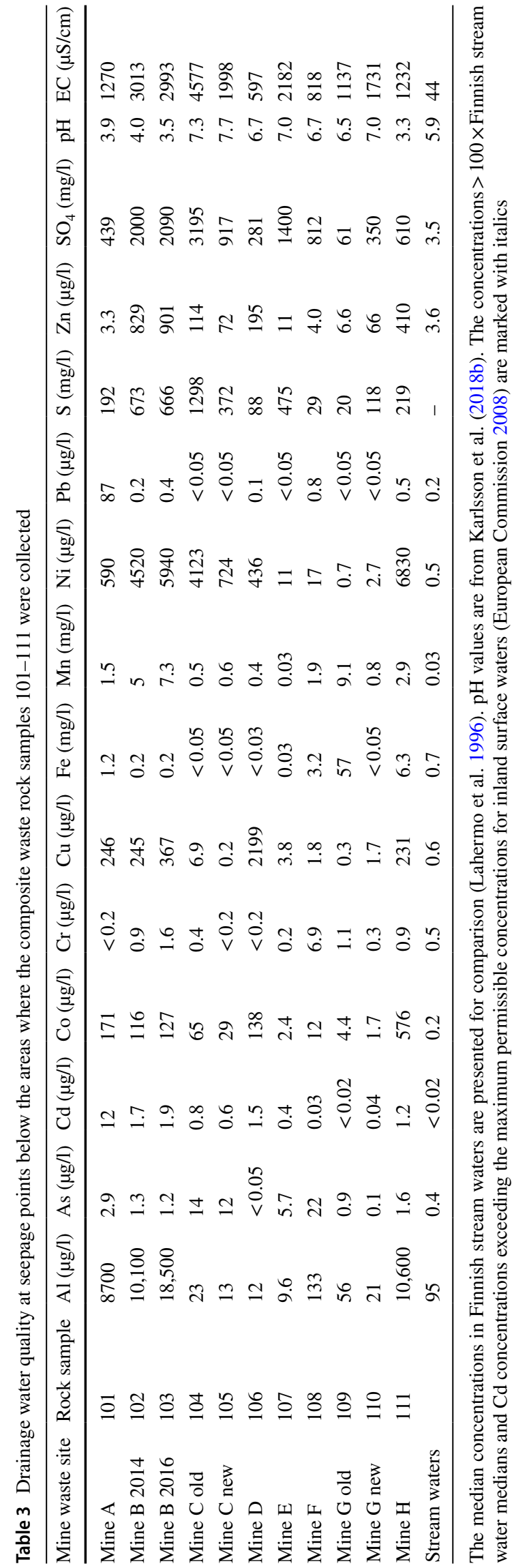


the maximum permissible concentrations for inland surface waters $(\leq 0.45-1.5 \mu \mathrm{g} / \mathrm{L}$, depending on classification based on water hardness) as defined in the European Commission Directive on environmental quality standards applicable to surface water (European Commission 2008). In addition, the $\mathrm{Cd}$ concentrations in Mine $\mathrm{C}$ new and Mine $\mathrm{E}$ drainage water exceeded the permissible mean annual concentrations $(\leq 0.08-0.25 \mu \mathrm{g} / \mathrm{L})$ stipulated in the Directive (European Commission 2008). It should be noted, that $\mathrm{As}, \mathrm{Co}$, and $\mathrm{Ni}$ were abundant also in some circumneutral drainage waters (Table 3).

Based on acidity and contaminant concentrations, drainage water from Mines A, B, and $\mathrm{H}$ waste rock sites can be classified as 'high-acid' and 'high-metal,' whereas drainage water from the Mines $C$ old and D waste rock sites can be classified as 'near-neutral' and 'high-metal.' In contrast, drainage water from the Mines C new, E, F, G (old and new) waste rock sites was 'near-neutral' and 'low-metal' (Plumlee et al. 1999) (Fig. 3).

\section{Discussion}

\section{Comparison of NAG test leachate analysis and AR extraction}

As expected, AR dissolution appeared to be more efficient in dissolving various minerals than the single-addition NAG test. The presumption was that the NAG test would leach elements bound to sulfide minerals and other more readily leachable mineral phases (Räisänen et al. 2010), and that AR would also partly leach some silicate mineral phases (Doležal et al. 1968; Niskavaara 1995). When comparing the single-addition NAG test and AR leachate results, the NAG test leachate concentrations were generally much less than the corresponding AR-extractable concentrations. This was particularly true for the elements originating from silicates and oxides, e.g. $\mathrm{Al}, \mathrm{Cr}$, and $\mathrm{Fe}$.

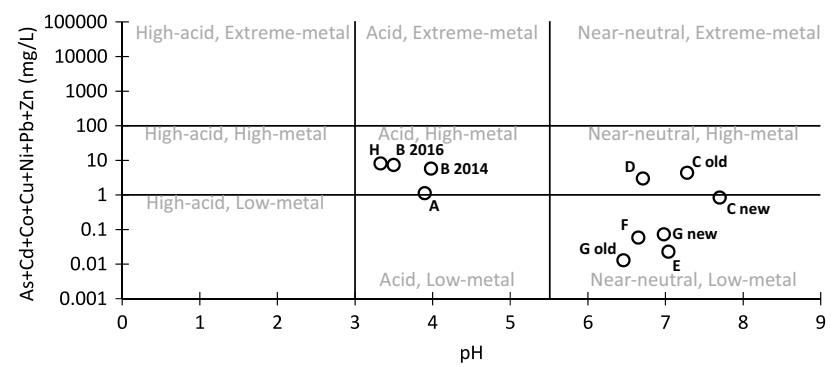

Fig. 3 A modified (the metalloid As added to the metal sum) Ficklin diagram (Plumlee et al. 1999) showing the quality of drainage water at the target waste rock facilities where water sampling was conducted
The greater leaching of $\mathrm{Cd}, \mathrm{Co}, \mathrm{Cu}, \mathrm{Ni}, \mathrm{Zn}$, and $\mathrm{S}$ compared with the other elements in the single-addition NAG test can be mainly explained by the oxidation of sulfide species, since they are chalcophile elements which occur typically in sulfides. In addition, the leaching of existing secondary minerals related to sulfide oxidation can increase the concentrations of chalcophile elements in the NAG test leachate. For example, $\mathrm{Cu}$ occurs mainly in sulfides and rarely in silicates (Koljonen 1992). Cobalt and Ni occur commonly together, mainly in sulfides, but also in mafic silicates, e.g. olivine, pyroxene and amphibole (Heikkinen and Räisänen 2009; Koljonen 1992). Zinc occurs both in sulfides and silicates. Silicates such as olivine, pyroxenes, amphiboles and biotite usually contain some $\mathrm{Zn}$ (Koljonen 1992). Cadmium usually occurs with $\mathrm{Zn}$, replacing it in the crystal structure of minerals (Koljonen 1992). Lower NAG/ AR ratios can also be related to the ability of AR to partly leach and etch silicates potentially bearing harmful elements (Chao and Sanzalone 1977; Doležal et al. 1968; Räisänen et al. 1992), which might not be as soluble in the singleaddition NAG test or in natural environments.

Incomplete sulfide oxidation in the single-addition NAG test has been previously documented (Stewart 2005; Parbhakar-Fox et al. 2018). According to AMIRA (2002), the single-addition NAG test is not suitable for samples containing $>1 \%$ sulfide $\mathrm{S}$ and high contents of readily available neutralising minerals (carbonates). This is because sulfides of high-S samples oxidise incompletely due, for example, to the catalytic decomposition of peroxide by metal ions released during sulfide oxidation. In the single-addition NAG test sulfide oxidation can already be incomplete in samples containing $>0.7 \mathrm{wt} \%$ of pyritic sulphide (Stewart 2005). Parbhakar-Fox et al. (2018) recommend multi-addition NAG test for low sulfide-S (i.e. $<0.3 \mathrm{wt} \%$ ) carbonatebearing samples, and the use of $30 \% \mathrm{H}_{2} \mathrm{O}_{2}$ for high sulfide-S materials (i.e. $>0.3 \mathrm{wt} \%$ ). It is also recommended that the multi-addition NAG test should supersede the single-addition NAG test entirely (Parbhakar-Fox et al. 2018).

According to our results, low $\mathrm{S}$ content in a sample does not guarantee a high NAG/AR ratio for S. Samples with low $(<0.2 \mathrm{wt} \%)$ total $\mathrm{S}$ can have NAG/AR ratios of wide range $(\approx 0.4-1)$. In general, samples with a lower NAG pH $(\leq 7)$ appear to be more dependent on the S content; the NAG/AR ratios for $\mathrm{S}$ decrease when the total $\mathrm{S}$ increases. As also stated by Parbhakar-Fox et al. (2018), the use of multi-addition NAG tests would enhance sulfide oxidation, which might lead to lower NAG test $\mathrm{pHs}$ and more realistic predictions of contaminant mobilization.

In addition to peroxide decomposition, the available sulfide surface area could also be related to NAG/AR S variation. The kinetics of sulfide oxidation is controlled by (for example) micro-textures (Parbhakar-Fox et al. 2013), mineral associations (Kwong 1993), and the precipitation 
of secondary minerals on sulfide surfaces (Al et al. 1997). If these factors affect the NAG test results, the NAG test results could also better reflect the sulfide oxidation process and effect of secondary mineral formation in the natural environment. The impact of these factors could not be verified in this study, as more detailed mineralogical investigation of the NAG test residues would be needed.

Results of the single-addition NAG test were dependent on the final $\mathrm{pH}$ of the test. In particular, the concentrations of $\mathrm{Cd}, \mathrm{Co}, \mathrm{Cu}, \mathrm{Ni}$, and $\mathrm{Zn}$ showed clear $\mathrm{pH}$ dependence. Their NAG/AR ratio was relatively high, (up to $0.5-1$ ) when the NAG $\mathrm{pH}$ was acidic $(<4.50)$, but dropped mainly to $\approx 0.1$ or less when the NAG test leachate $\mathrm{pH}$ was between 5 and 6. A decrease in element concentrations with higher $\mathrm{pH}$ in NAG test leachate has also been noted in previous studies (Barnes et al. 2015; Charles et al. 2015; Karlsson and Kauppila 2016; Karlsson et al. 2018a; Räisänen et al. 2010) and can be explained by the formation of secondary precipitates during the test at higher $\mathrm{pH}$ (Charles et al. 2015), coinciding with decreasing $\mathrm{Al}$ and $\mathrm{Fe}$ concentrations and retention of elements by adsorption at elevated $\mathrm{pH}$ (Barnes et al. 2015).

\section{Interpretation of Single-addition NAG test leachate Analysis and AR Extraction Results in Drainage Quality Prediction}

The performance of AR and single-addition NAG test methods in drainage quality prediction varied for different elements. Overall, the elevated AR-extractable As, $\mathrm{Cd}, \mathrm{Co}, \mathrm{Cu}$, $\mathrm{Ni}$, and $\mathrm{Zn}$ concentrations reflected elevated concentrations in the drainage, especially in acidic water systems. For Al, $\mathrm{As}, \mathrm{Cd}, \mathrm{Co}, \mathrm{Cu}$ and $\mathrm{Ni}$, elevated AR-extractable concentrations did not correspond to elevated drainage concentrations in some circumneutral water systems. The NAG test method predicted elevated drainage concentrations for $\mathrm{Al}, \mathrm{Cd}, \mathrm{Co}$, $\mathrm{Cu}, \mathrm{Ni}$, and $\mathrm{Zn}$, but only when the NAG test leachate $\mathrm{pH}$ was low. The abundance of As and Ni in some circumneutral drainage waters suggests that the single-addition NAG test leachate concentrations were not useful drainage quality indicators in these cases. The AR-extractable $\mathrm{Cr}$ concentrations were high in many cases and did not correlate with the low drainage concentrations. In contrast, the acidic NAG test leachate concentrations of $\mathrm{Cr}$ were low, reflecting low drainage concentrations. $\mathrm{Cr}$ is bound mainly to silicates and oxides (e.g. Salminen et al. 2005), and therefore has poor mobilisation in rock weathering processes (e.g. Koljonen 1992; Räisänen et al. 2010). Similarly, a high ARextractable $\mathrm{Al}$ concentration did not correspond to a high drainage concentration, especially in circumneutral drainage systems, likely because AR extraction partly leaches some silicates that are not significantly weathered in circumneutral natural environments (e.g. biotite; Doležal et al. (1968)). In this study, the abundance of biotite, an Al-bearing silicate, corresponded with high AR extractable Al concentrations (e.g. see samples 1, 25, 26, 28, 29, 34, 101, and 112). It should be noted that the leachable concentrations in AR extraction and in acidic, single-addition NAG tests are not intended to provide a direct measure of the concentrations of contaminants in drainage water, but only to indicate where elevated concentrations are likely (Fig. 4).

In general, elevated concentrations of contaminants in the AR-extractable fraction of surface waste rock samples were reflected in elevated concentrations in drainage water (Fig. 5). Similar results have been reported in previous studies (Price et al. 1997; Fosso-Kankeu et al. 2015; Karlsson and Kauppila 2016; Karlsson et al. 2018a). It can be generalised that if the AR-extractable sum of $\mathrm{As}, \mathrm{Cd}, \mathrm{Co}, \mathrm{Cu}, \mathrm{Ni}$ and $\mathrm{Zn}$ is $>1000 \mathrm{mg} / \mathrm{kg}$, there is a high risk for a high-metal drainage (the sum of harmful metals and metalloids $>1000$ $\mu \mathrm{g} / \mathrm{L}$, as in Plumlee et al. 1999). In the cases of Mine A and Mine $\mathrm{C}$ new, the water samples were collected from a pond, which may have been diluted by other water sources and therefore had lower overall drainage concentrations. Thus, and when considering the higher drainage concentrations in the case of Mine $\mathrm{C}$ old with similar rock material, it can also be assumed that the Mine $\mathrm{C}$ new drainage could be classified as 'high-metal' water.

Overall, the analysis of single-addition NAG test leachate is also a suitable method for predicting contaminants in waste rock and its drainage water. However, as the leachable concentrations of contaminants in the single-addition NAG test decrease when the NAG test $\mathrm{pH}$ increases, high concentrations in NAG test leachate can only indicate elevated concentrations in drainage water under acidic NAG test conditions, as also stated by Barnes et al. (2015). Nonetheless, as can be noted in the case of Mine D site, the NAG test can predict contaminant mobilization in neutral drainage if the test $\mathrm{pH}$ is sufficiently low for the contaminants not to precipitate, but in then the test $\mathrm{pH}$ does not reflect the drainage $\mathrm{pH}$. In general, if the sum of $\mathrm{As}, \mathrm{Cd}, \mathrm{Co}, \mathrm{Cu}, \mathrm{Ni}$, and $\mathrm{Zn}$ in NAG test leachate is $>500 \mathrm{mg} / \mathrm{kg}$, there is an elevated risk for high-metal drainage. As discussed above, $<500 \mathrm{mg} / \mathrm{kg}$ in NAG test leachate does not exclude the risk for high-metal drainage in circumneutral drainage systems. The usability of the method in neutral mine drainage cases should be further investigated.

According to the results of this study, the presence of $\mathrm{Ca}-$ and $\mathrm{Mg}$-bearing minerals resulted in unrealistically high NAG test $\mathrm{pH}$ values. The NAG test $\mathrm{pH}$ of several samples was abnormally high, up to 10.8 (sample 109 from Mine $\mathrm{G}$ old), although the related drainage $\mathrm{pH}$ was circumneutral. In general, high $(>8) \mathrm{NAG} \mathrm{pH}$ values seem to be related to the presence of $\mathrm{Ca}$ and $\mathrm{Mg}$ bearing minerals, e.g. carbonates, diopside/tremolite, serpentine, olivine, and talc (for example, see samples 2, 3, 6, 8, 16, 17, 18, $19,20,25,37,109$, and 110). Parbhakar-Fox et al. (2018) 

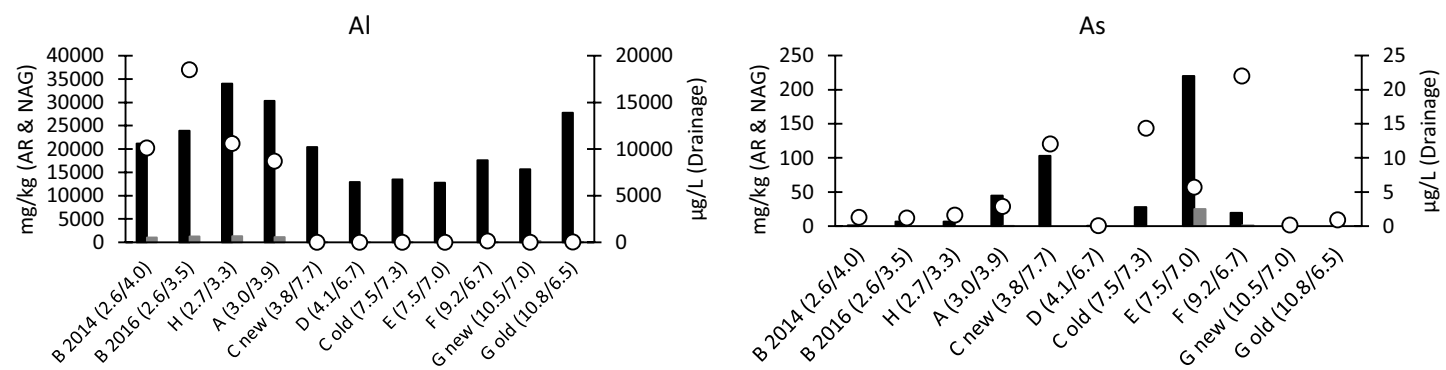

Cd
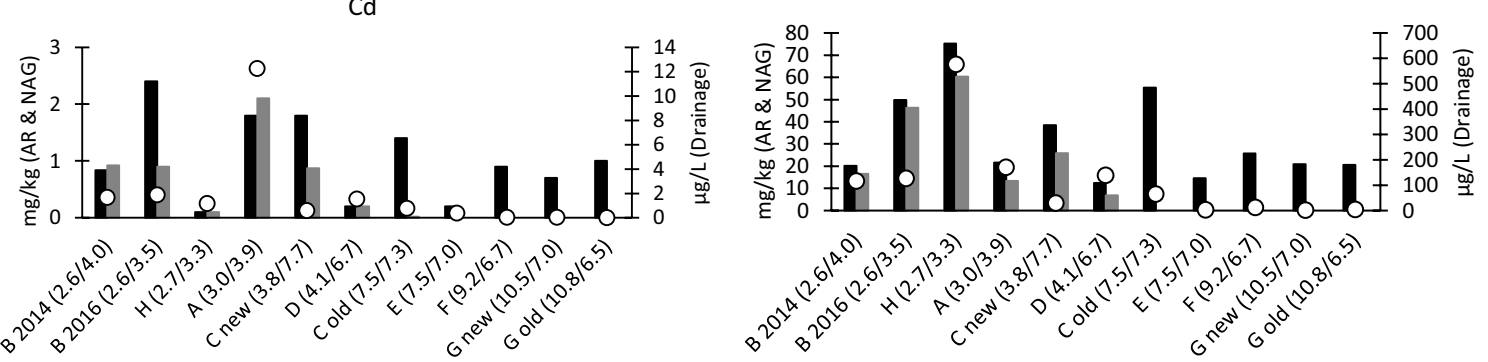

$\mathrm{Cr}$
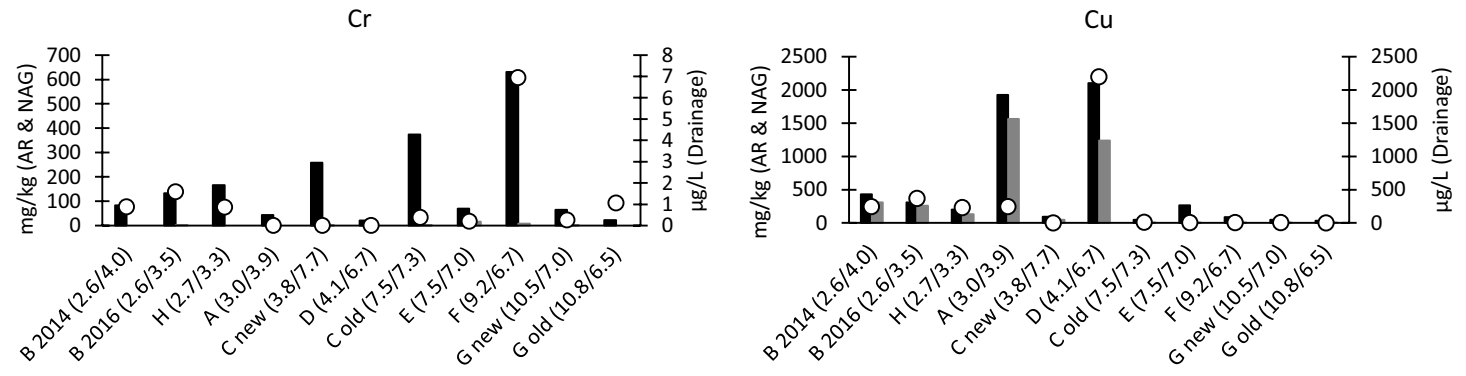

$\mathrm{Mn}$
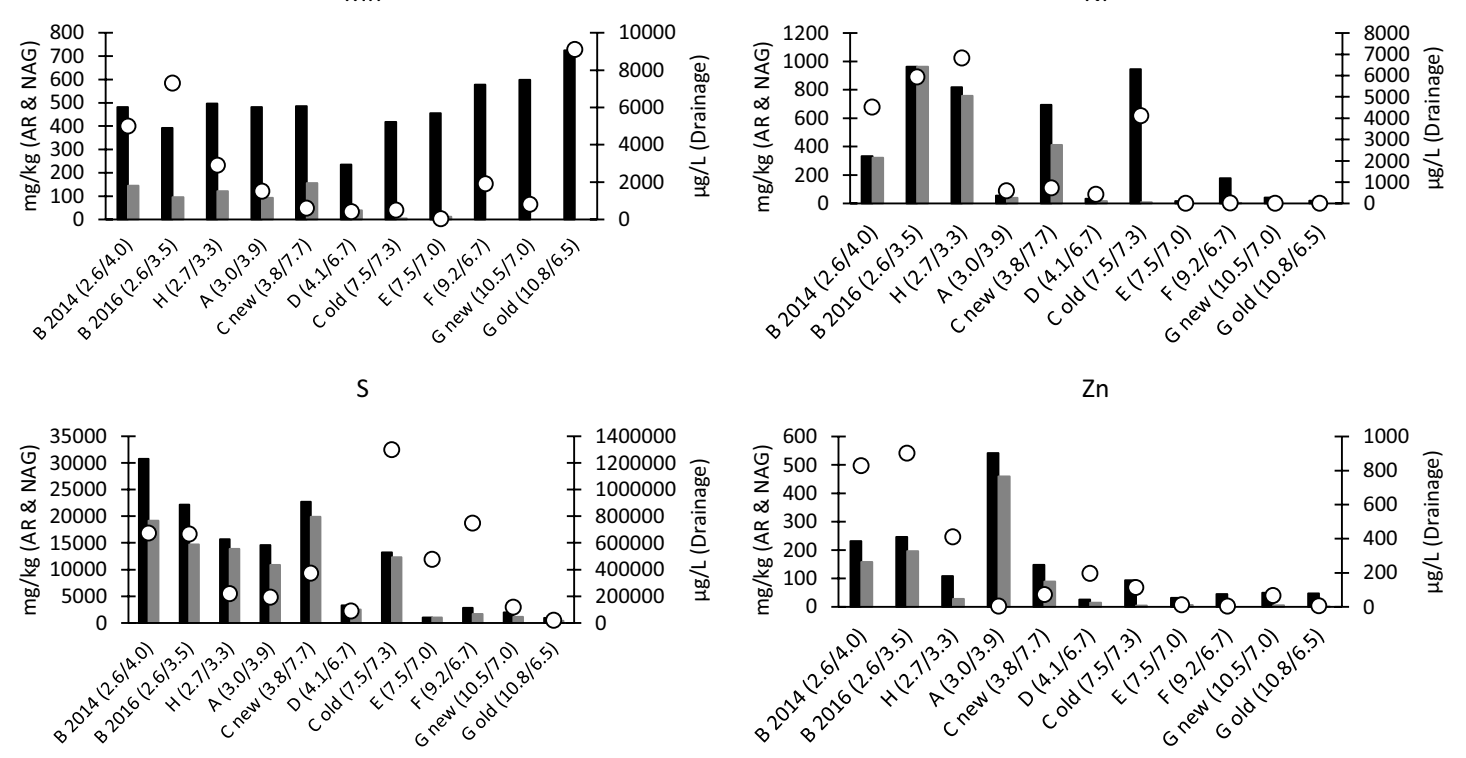

- AR NAG O Drainage

Fig. 4 NAG test leachate concentrations and AR-extractable concentrations of $\mathrm{Al}, \mathrm{As}, \mathrm{Cd}, \mathrm{Co}, \mathrm{Cr}, \mathrm{Cu}, \mathrm{Mn}, \mathrm{Ni}, \mathrm{S}$ and $\mathrm{Zn}$ in composite waste rock samples and in the corresponding drainage water. The
NAG test and drainage $\mathrm{pH}$ values are shown in brackets after the sample name (NAG test/drainage) 


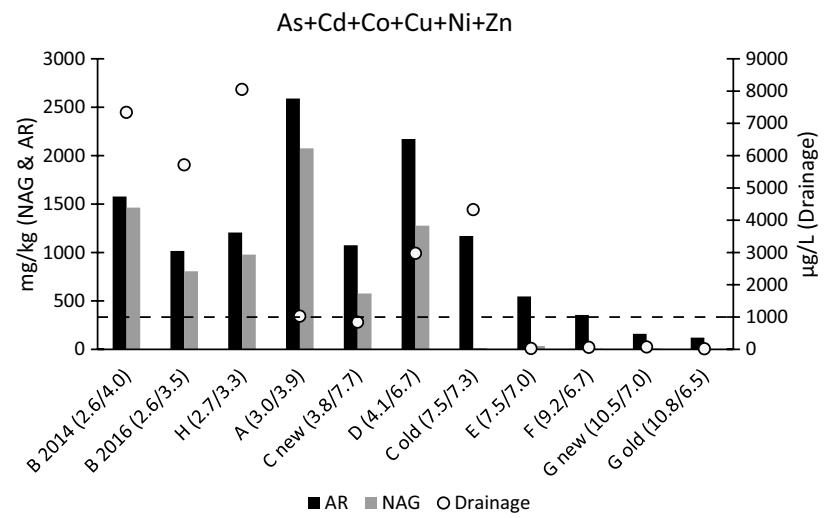

Fig. 5 The sums of NAG test leachate As, $\mathrm{Cd}, \mathrm{Co}, \mathrm{Cu}, \mathrm{Ni}$ and $\mathrm{Zn}$ concentrations and AR-extractable concentrations in composite waste rock samples and in the corresponding drainage water of the mine sites. The NAG test and drainage $\mathrm{pH}$ values are shown in brackets after the sample name (NAG test/drainage). The mine sites are presented in the order of increasing NAG pH. The dashed black line presents $1000 \mu \mathrm{g} / \mathrm{L}$ in drainage

recommended multi-addition NAG test for low sulfide-S $(<0.3 \mathrm{wt} \%)$ carbonate-bearing samples, but according to this study, the commonly used single-addition NAG test was not representative for samples containing $\mathrm{Ca}$ and $\mathrm{Mg}$ silicate. It can be assumed that samples with high contents of $\mathrm{Ca}$ and $\mathrm{Mg}$ bearing carbonates and silicates will result in abnormally high, single-addition NAG $\mathrm{pH}$, and NAG test leachate analysis gives a poor prediction of contaminant mobilization due to enhanced precipitation processes.

Waste rock characterisation and drainage quality predictions made using data from small-scale laboratory tests have limitations. For example, mineral assemblage and surface area, rock texture, and mineral impurities may affect the weathering rate, as would a small sample size and crushing of the samples (Dold 2017; Jambor 2003; Paktunc 1999; Parbhakar-Fox and Lottermoser 2015; White III et al. 1999). Representative sampling is key to successful waste rock characterisation (Price 2009). To assess drainage water quality based on AR and singleaddition NAG test leachate analysis of waste rock samples, only composite surface samples were collected for this study, which should be considered when interpreting the results. More comprehensive waste rock sampling techniques were presented by McLemore et al. (2014). In addition, drainage water samples represented only one sampling campaign. For drainage water quality measurements, a more long-lasting monitoring campaign is recommended, as the contaminant concentrations in mine waste drainage water may display wide annual and seasonal fluctuations (Alakangas et al. 2010; González et al 2020; Heikkinen et al. 2009; Søndergaard et al. 2007). Future work will examine waste rock history, dump cores, drainage quality changes etc. in more detail. It should also be noted that the concentrations measured in this study do not necessarily represent any official mine waste or drainage concentrations monitored at the mine sites.

Small-scale laboratory tests such as AR extraction and NAG test leachate analysis are useful for preliminary screening in the drainage water quality assessment of waste rocks, but more thorough and site-specific investigations such as kinetic testing and geochemical modelling should still be conducted. Although the single-addition NAG test and ARD prediction results have known limitations (e.g. ParbhakarFox and Lottermoser 2015; Parbhakar-Fox et al. 2018), the test is still widely used. The results of this study indicated that the analysis of single-addition NAG test leachate can be used in site-specific drainage water quality assessment at potentially acid forming (PAF) waste rock sites, both in assessing the acid production potential and in predicting which contaminants might occur in elevated concentrations in the drainage water. For non-acid forming (NAF) rock types containing high amounts of $\mathrm{Ca}$ - and $\mathrm{Mg}$-bearing carbonates and silicates, the AR extraction better predicts which elements will be potentially mobilized. In these cases, the multi-step NAG test might also produce more realistic predictions, but this needs further verification. Although many elements tend to precipitate in higher $\mathrm{pH}$ single-addition NAG test leachates, $\mathrm{H}_{2} \mathrm{O}_{2}$ seems to leach most potential contaminants efficiently. Our results indicate that a $\mathrm{H}_{2} \mathrm{O}_{2}$-based leach might be more selective for contaminant mobility assessment than the more aggressive AR extraction, which also partially leaches many silicates.

\section{Conclusions}

The most widely-abundant contaminants at Finnish waste rock drainage sites investigated in this study were $\mathrm{Co}, \mathrm{Ni}$, $\mathrm{Cu}$, and $\mathrm{Cr}$. $\mathrm{Cd}$, $\mathrm{Co}$ and $\mathrm{Ni}$ had high concentrations at five of the eight investigated mine sites, and $\mathrm{Cu}$ was abundant at four mine sites. These elements also appeared in some circumneutral water systems. In waste rocks, AR-extractable $\mathrm{Co}, \mathrm{Ni}, \mathrm{Cu}$, and $\mathrm{Cr}$ often exceeded the PIMA guideline values.

Elevated concentrations of contaminants in the ARextractable fraction of surface waste rock samples seemed to reflect elevated concentrations in the drainage water. If the AR-extractable sum of $\mathrm{As}, \mathrm{Cd}, \mathrm{Co}, \mathrm{Cu}, \mathrm{Ni}$, and $\mathrm{Zn}$ was $>1000 \mathrm{mg} / \mathrm{kg}$, there was an elevated risk for highmetal $(>1000 \mu \mathrm{g} / \mathrm{L})$ drainage. Elevated AR-extractable Al, $\mathrm{As}, \mathrm{Cd}, \mathrm{Co}, \mathrm{Cu}$, and $\mathrm{Ni}$ concentrations reflected elevated concentrations in acidic drainage water, but overestimated contaminant mobility in some circumneutral drainage cases, and $\mathrm{Cr}$ in general. For example, the abundance of biotite, an Al-bearing silicate, correlated with high AR extractable $\mathrm{Al}$ 
concentrations, although $\mathrm{Al}$ is not mobile in circumneutral drainage systems.

Analysis of single-addition NAG test leachate was also useful for assessing the mobility of $\mathrm{Al}, \mathrm{Cd}, \mathrm{Co}, \mathrm{Cr}, \mathrm{Cu}, \mathrm{Ni}$, and $\mathrm{Zn}$ in acid drainage cases. In some high-metal NMD cases, the predictioned mobilities were too low. The usability of single-addition NAG test leachate analysis in neutral mine drainage cases should be further investigated. Most of the contaminants precipitated when the leachate $\mathrm{pH}$ was above 3-6. If the sum of $\mathrm{As}, \mathrm{Cd}, \mathrm{Co}, \mathrm{Cu}, \mathrm{Ni}$, and $\mathrm{Zn}$ in NAG test leachate was $>500 \mathrm{mg} / \mathrm{kg}$, there seemed to be high risk for a high-metal drainage. On the other hand, $<500 \mathrm{mg} / \mathrm{kg}$ in NAG test leachate did not exclude the risk for high-metal drainage in circumneutral systems. The presence of $\mathrm{Ca}$ - and Mg-bearing minerals such as carbonates, diopside/tremolite, serpentine, olivine, and talc can result in unrealistically high NAG test $\mathrm{pH}$ values. Use of multi-addition NAG tests for low sulfide, carbonate, and $\mathrm{Ca}$ - and $\mathrm{Mg}$-silicate bearing samples is recommended.

Sulfides appeared to be incompletely leached in the single-addition NAG test, even when their concentrations were low (tot-S $<0.2 \mathrm{wt} \%$ ). Using the multi-addition NAG test would enhance sulfide oxidation, which might lead to lower NAG test $\mathrm{pHs}$ and provide more realistic predictions of contaminant mobilization. The multi-addition NAG test or another $\mathrm{H}_{2} \mathrm{O}_{2}$-based leach might be more selective for element mobility assessment in the circumneutral cases than the more aggressive AR extraction. Further investigations and verification are needed.

Supplementary Information The online version contains supplementary material available at https://doi.org/10.1007/s10230-021-00784-0.

Acknowledgements The data for this study were collected as part of the basic mining environmental research of the Geological Survey of Finland (GTK), the Closedure project (2012-2015) funded by the Finnish Funding Agency for Technology and Innovation (Tekes) Green Mining Programme and the KaiHaMe project (2015-2018) funded by the European Regional Development Fund. The authors thank the mining companies for participating in these investigations and for facilitating the necessary field work.

Open Access This article is licensed under a Creative Commons Attribution 4.0 International License, which permits use, sharing, adaptation, distribution and reproduction in any medium or format, as long as you give appropriate credit to the original author(s) and the source, provide a link to the Creative Commons licence, and indicate if changes were made. The images or other third party material in this article are included in the article's Creative Commons licence, unless indicated otherwise in a credit line to the material. If material is not included in the article's Creative Commons licence and your intended use is not permitted by statutory regulation or exceeds the permitted use, you will need to obtain permission directly from the copyright holder. To view a copy of this licence, visit http://creativecommons.org/licenses/by/4.0/.

\section{References}

Al TA, Blowes DW, Martin CJ, Cabri LJ, Jambor JL (1997) Aqueous geochemistry and analysis of pyrite surfaces in sulfide-rich mine tailings. Geochim Cosmochim Ac 61(12):2353-2366

Alakangas L, Lundberg A, Öhlander B (2010) Estimation of temporal changes in oxidation rates of sulfides in copper mine tailings at Laver, northern Sweden. Sci Total Environ 408(6):1386-1392

AMIRA (2002) ARD Test Handbook Project P387A, Prediction and Kinetic Control of Acid Mine Drainage. AMIRA International, Melbourne

Barnes A, Bowell R, Warrender R, Sapsford D, Sexsmith K, Charles J, Declercq J, Santonastaso M, Dey M (2015) Comparison between long-term humidity cell testing and static net acid generation (NAG) tests: potential for NAG use in preliminary mine site water quality predictions. In: Brown A, Bucknam C, Burgess J, Carballo M, Castendyk D, Figueroa L, Kirk L, McLemore V, McPhee J, O'Kane M, Seal R, Wiertz J, Williams D, Wilson W, Wolkersdorfer C (eds), Proceedings, 10th ICARD and IMWA 2015 Conference, Santiago, Chile, pp 695-704

Chao TT, Sanzalone RJ (1977) Chemical dissolution of sulfide minerals. J Res US Geol Surv 5:409-412

Charles J, Barnes A, Declercq J, Warrender R, Brough C, Bowell R (2015) Difficulties of interpretation of NAG test results on net neutralizing mine wastes: initial observations of elevated $\mathrm{pH}$ conditions and theory of $\mathrm{CO}_{2}$ disequilibrium. In: Brown A, Bucknam C, Burgess J, Carballo M, Castendyk D, Figueroa L, Kirk L, McLemore V, McPhee J, O'Kane M, Seal R, Wiertz J, Williams D, Wilson W, Wolkersdorfer C (eds), Proceedings, 10th ICARD and IMWA 2015 conferences, Santiago, Chile, pp 575-584

Criss JW, Birks LS (1968) Calculation methods for fluorescent x-ray spectrometry. Empirical coefficients versus fundamental parameters. Anal Chem 40:1080-1086

Dold B (2014) Evolution of acid mine drainage formation in sulfidic mine tailings. Minerals 4(2):621-641

Dold B (2017) Acid rock drainage prediction: a critical review. J Geochem Explor 172:120-132

Doležal J, Provondra P, Šulcek Z (1968) Decomposition techniques in inorganic analysis. Iliffe Books Ltd, London

European Commission (2008) Directive 2008/105/EC of the European Parliament and of the Council on environmental quality standards in the field of water policy. https://eur-lex.europa.eu/ legal-content/EN/TXT/?uri=celex:32008L0105. Accessed 16 Dec 2008

Fosso-Kankeu E, Waanders F, Mulaba-Bafubiandi A, Sidu S (2015) Leachability of suspended particles in mine water and risk of water contamination. In: Brown A, Bucknam C, Burgess J, Carballo M, Castendyk D, Figueroa L, Kirk L, McLemore V, McPhee J, O'Kane M, Seal R, Wiertz J, Williams D, Wilson W, Wolkersdorfer C (eds) Proceedings, 10th ICARD and IMWA 2015 conference, Santiago, Chile, pp 788-796

González RM, Cánovas CR, Olías M, Macías F (2020) Seasonal variability of extremely metal rich acid mine drainages from the Tharsis mines (SW Spain). Environ Pollut 259:113829. https:// doi.org/10.1016/j.envpol.2019.113829

Finnish Government (2013) Government Decree on Extractive Waste 190/2013. Finnish Government, Helsinki, Finland. https://www. finlex.fi/fi/laki/kaannokset/2013/en20130190_20150102.pdf. Accessed 14 Oct 2020

Finnish Government (2007) Government decree on the assessment of soil contamination and remediation needs 214/2007. Finnish Government, Helsinki, Finland. www.finlex.fi/fi/laki/kaann okset/2007/en20070214.pdf. Accessed 14 Oct 2020 
Heikkinen PM, Räisänen ML (2009) Trace metal and As solid-phase speciation in sulfide mine tailings-indicators of spatial distribution of sulfide oxidation in active tailings impoundments. Appl Geochem 24:1224-1237

Heikkinen PM, Räisänen ML, Johnson RH (2009) Geochemical characterisation of seepage and drainage water quality from two sulfide mine tailings impoundments: acid mine drainage versus neutral mine drainage. Mine Water Environ 28:30-49

ISO (1995a) Soil quality-Determination of organic and total carbon after dry combustion (elementary analysis). DIN ISO 10694:1995-2003

ISO (1995b) Soil quality-extraction of trace elements soluble in aqua regia. DIN ISO 11466:1995-2003

ISO (2000) Soil quality - determination of total sulfur by dry combustion. DIN ISO 115178:2000-2011

ISO/IEC (2005) General requirements for the competence of testing and calibration laboratories. DIN ISO/IEC 17025:2005-2011

Jambor JL (2003) Mine-waste mineralogy and mineralogical perspectives of acid-base accounting. In: Jambor JL, Blowes DW (eds) The environmental geochemistry of sulfide mine-wastes, short course handbook, vol 22. Mineralogical Association of Canada, Ottawa, pp 59-102

Jennings SR, Dollhopf DJ, Inskeep WP (2000) Acid production from sulfide minerals using hydrogen peroxide weathering. Appl Geochem 15:235-243

Karlsson T, Kauppila PM (2016) Waste rock characterization versus the actual seepage water quality. In: Drebenstedt C, Paul M (eds), Proceedings, IMWA 2016 - Mining Meets Water - Conflicts and Solutions, TU Bergakademie, Freiberg, Germany, pp 402-406

Karlsson T, Räisänen ML, Lehtonen M, Alakangas L (2018b) Comparison of static and mineralogical ARD prediction methods in the Nordic environment. Environ Monit Assess. https://doi.org/ 10.1007/s10661-018-7096-2

Karlsson T, Kauppila P, Lehtonen M (2018a) Prediction of the longterm behaviour of extractive wastes based on environmental characterisation: correspondence of laboratory prediction tests with field data. Bull Geol Surv Finland 408:11-26

Kauppila PM, Räisänen ML (2015) Effluent chemistry of closed sulfide mine tailings - influence of ore type. In: Brown A, Bucknam C, Burgess J, Carballo M, Castendyk D, Figueroa L, Kirk L, McLemore V, McPhee J, O'Kane M, Seal R, Wiertz J, Williams D, Wilson W, Wolkersdorfer C (eds), Proceedings, 10th ICARD and IMWA conference, pp 264-273

Koljonen T (ed) (1992) The geochemical atlas of Finland, Part 2: Till. Geological Survey of Finland, Espoo, Finland, $218 \mathrm{p}$

Kwong YTJ (1993) Prediction and prevention of acid rock drainage from a geological and mineralogical perspective. MEND report 1.32.1, Canmet, Ottawa, Canada. http://mend-nedem.org/wpcontent/uploads/1.32.1.pdf. Accessed 14 Oct 2020

Lahermo P, Väänänen P, Tarvainen T, Salminen R (1996) Geochemical Atlas of Finland, Part 3: Environmental Geochemistry Stream Waters and Sediments. Geological Survey of Finland, Espoo, Finland, $147 \mathrm{p}$

Lapakko K (2002) Metal mine rock and waste characterization tools: an overview. Mining, Minerals, and Sustainable Development 67, 1-31

Lei L, Watkins R (2005) Acid drainage reassessment of mining tailings, Black Swan Nickel Mine, Kalgoorlie, Western Australia. Appl Geochem 20:661-667

McLemore V, Smith K, Russell C (2014) Sampling and monitoring for the mine life cycle. Society for Mining, Metallurgy and Exploration, Englewood

MEND (1991) Acid rock drainage prediction manual. MEND project 1.16.1b. Canmet-MSL division, Dept of Energy, Mines and
Resources, Ottawa, Canada. http://mend-nedem.org/wp-content/ uploads/2013/01/1.16.1b.pdf. Accessed 14 Oct 2020

Miller S, Robertson A, Donahue T (1997) Advances in acid drainage prediction using the net acid generating (NAG) test. In: Gusek J, Wildeman T (eds) Proceedings, 4th international conference on acid rock drainage (ICARD). Canada, vol II, pp 533-547

Muniruzzaman M, Kauppila PM, Karlsson T (2018) Water quality prediction of mining waste facilities based on predictive models. Open File Research Report 16/2018. Geological Survey of Finland, Espoo, Finland. http://tupa.gtk.fi/raportti/arkisto/16_2018. pdf. Accessed 14 Oct 2020

Nieva NE, Borgnino L, García MG (2018) Long term metal release and acid generation in abandoned mine wastes containing metalsulfides. Environ Pollut 242:264-276

Niskavaara H (1995) A comprehensive scheme of analysis for soils, sediments, humus and plant samples using inductively coupled plasma atomic emission spectrometry (ICP-AES). In: Autio S (ed), Geological Survey of Finland, Current Research 1993 1994. Geological Survey of Finland, Espoo, Special Paper 20, pp. $167-175$

Nordstrom DK, Nicholson A (2017) Geochemical modeling for mine site characterization and remediation. Society for Mining, Metallurgy and Exploration, Englewood

Paktunc AD (1999) Mineralogical constrains of the determination of neutralization potential and prediction of acid mine drainage. Environ Geol 39(2):103-112

Parbhakar-Fox A, Lottermoser BG (2015) A critical review of acid rock drainage prediction methods and practices. Miner Eng $82: 107-124$

Parbhakar-Fox A, Lottermoser B, Bradshaw D (2013) Evaluating waste rock mineralogy and microtexture during kinetic testing for improved acid rock drainage prediction. Miner Eng 52:111-124

Parbhakar-Fox A, Fox N, Ferguseon T, Hill R, Maynard B (2018) Dissection of the NAG pH test: tracking efficacy through examining reaction products. In: Wolkersdorfer C, Sartz L, Weber A, Burgess J, Tremblay G (eds) Proceedings, IMWA 2018 - Risk to Opportunity, Pretoria, South Africa, pp 949-955

Plumlee GS, Smith KS, Mountour MR, Ficklin WH, Mosier EL (1999) Geologic controls on the composition of natural waters and mine waters draining diverse mineral-deposit types. In: Plumlee GS, Filipek LH (eds), The environmental geochemistry of mineral deposits, part B: case studies and research topics. Rev Econ Geol 6(B):373-432

Price WA (2003) Challenges posed by metal leaching and acid rock drainage, and approaches used to address them. In: Jambor JL, Blowes DW, Ritchie AIM (eds) Environmental aspects of mine wastes. Mineralogical Association of Canada, Short Course Series, vol 31, pp 15-30

Price WA (2009) Prediction Manual for Drainage Chemistry from Sulfidic Geologic Materials. MEND Report 1.20.1, Canmet, Smithers, British Columbia

Price WA, Morin K, Hutt N (1997) Guidelines for prediction of acid rock drainage and metal leaching for mines in British Columbia: part II. Recommended procedures for static and kinetic tests. In: Gusek J, Wildeman T (eds), 4th ICARD, Vancouver, vol I, pp $15-30$

Räisänen ML, Tenhola M, Mäkinen J (1992) Relationship between mineralogy and the physicochemical properties of till in central Finland. Bull Geol Soc Finland 64(1):35-58

Räisänen ML, Kauppila PM, Myöhänen T (2010) Suitability of static tests for acid rock drainage assessment of mine waste rock. Bull Geol Soc Finl 82:101-111

Reinikainen J (2007) Criteria for determining the soil threshold and guide line values. Finnish Environment 23/2007. Helsinki: Finnish Environment Institute (in Finnish) 
Ross C, Verburg R (2015) Lessons learned in the interpretation of mine waste static testing results. In: Brown A, Bucknam C, Burgess J, Carballo M, Castendyk D, Figueroa L, Kirk L, McLemore V, McPhee J, O'Kane M, Seal R, Wiertz J, Williams D, Wilson W, Wolkersdorfer C (eds) Proceedings, 10th ICARD and IMWA 2015 conference, pp 627-635

Salminen R, Batista MJ, Bidovec M, Demetriades A et al (2005) Geochemical Atlas of Europe. Part 1: background information, methodology and maps. Geological Survey of Finland, Espoo

SFS-EN (2012) Characterization of waste. Static test for determination of acid potential and neutralization potential of sulfidic waste. DIN SFS-EN 15875-03

Singer PC, Stumm W (1970) Acid mine drainage: the rate-determining step. Science 167:1121-1123

Sobek A, Schuller W, Freemen J, Smith R (1978) Field and Laboratory Methods Applicable to Overburdens and Minesoils. Report EPA600/z-78-054, US Environmental Protection Agency, Cincinnati Søndergaard J, Elberling B, Asmund G, Gudrum C, Iversen KM (2007) Temporal trends of dissolved weathering products from a high
Arctic coal mine waste rock pile in Svalbard $\left(78^{\circ} \mathrm{N}\right)$. Appl Geochem 22:125-138

Stewart WA (2005) Development of acid rock drainage prediction methodologies for coal mine wastes. PhD Diss, University of South Australia

Weber PA, Stewart WA, Skinner WM, Weisener CG, Thomas JE, Smart RStC (2004) Geochemical effects of oxidation products and framboidal pyrite oxidation in acid mine drainage prediction techniques. Appl Geochem 19:1953-1974

White WW III, Lapakko KA, Cox RL (1999) Static-test methods most commonly used to predict acid mine drainage: Practical guidelines for use and interpretation. In: Plumlee GS, Logsdon MJ, Filipek LF (eds), The environmental geochemistry of mineral deposits, part A: processes, techniques, and health issues. Society of Economic Geologists Reviews in Economic Geology, vol. 7A, pp $325-328$ 